Hispania, 2021, vol. LXXXI, n. . 269, septiembre-diciembre, págs. 797-825 ISSN: 0018-2141, e-ISSN: 1988-8368, https://doi.org/10.3989/hispania.2021.021

\title{
Entre la neutralidad y la lealtad: el embajador Areilza y la Guerra de Argelia*
}

\author{
Pablo Guerrero García ${ }^{1}$ \\ Universidad Francisco de Vitoria \\ pablo.guerrero@ufv.es
}

RESUMEN: Este artículo de investigación aborda las gestiones diplomáticas al más alto nivel efectuadas en el transcurso de la última fase de la guerra de Argelia por José María de Areilza (1909-1998), quien se desempeñó como embajador de España en Francia entre 1960 y 1964. Apoyándose en documentos diplomáticos, primordialmente cartas e informes, así como en el testimonio retrospectivo de Areilza mismo, cuyo contenido se matiza a la luz de la documentación archivística consultada, el artículo expone cómo el embajador Areilza propugnó ante el Ministerio de Asuntos Exteriores español, hasta abril de 1961, una política de equidistancia entre los partidarios y los detractores de la politica argelina del presidente De Gaulle, un conflicto intestino que había dividido profundamente a la sociedad y al ejército franceses. Una vez fracasada la sublevación de los generales antigaullistas en Argel y pese a las simpatías que la causa de los golpistas despertaba en algunos sectores del régimen de Franco, Areilza planteará abiertamente la necesidad de colaborar estrechamente con el Gobierno francés a fin de obtener de este el respaldo a la solicitud española de asociación al Mercado Común.

\section{Palabras clave: Areilza; De Gaulle; Guerra de Argelia; Castiella; OAS; Salan.}

\footnotetext{
* Las cartas, despachos e informes citados en el presente artículo proceden del Archivo General de la Administración, Alcalá de Henares, Madrid (AGA), Fondo del Ministerio de Asuntos Exteriores; del Archivo de la Fundación Nacional Francisco Franco, Madrid (AFNFF); y del fondo personal de la profesora de Historia Contemporánea en la Universidad Nacional de Educación a Distancia (UNED) Rosa Pardo (ARP), a quien agradezco su desinteresada e inestimable colaboración.
}

${ }^{1}$ ORCID iD: https://orcid.org/0000-0003-2535-6540

Copyright: (C) 2021 CSIC. Este es un artículo de acceso abierto distribuido bajo los términos de una licencia de uso y distribución Creative Commons Reconocimiento 4.0 Internacional (CC-BY 4.0) 


\section{Between neutrality and loyalty: Ambassador Areilza and the Algerian War}

ABSTRACT: This research article addresses diplomatic efforts made at the highest level during the last phase of the Algerian War by José María de Areilza (1909-1998), who served as Spain's ambassador to France between 1960 and 1964. Drawing on diplomatic documents, primarily letters and reports, along with the retrospective testimony of Areilza himself, the content of which is qualified in the light of the archival documentation consulted, the article studies how, up until April 1961, Ambassador Areilza was urging the Spanish Ministry of Foreign Affairs to adopt a policy of equidistance between supporters and opponents of President de Gaulle's Algerian policy, an internal conflict that had deeply divided both French society and its army. Once the Algiers putsch failed and despite the sympathies the rebel generals enjoyed in some sectors of the Franco regime, Areilza openly advocated the need to work closely with the French Government in order to gain its support for Spain's application to become an associate member of the European Economic Community.

Key words: Areilza; De Gaulle; Algerian War; Castiella; OAS; Salan.

CÓMO CITAR ESTE ARTÍCULO / CITATION: Guerrero García, Pablo, «Entre la neutralidad y la lealtad: el embajador Areilza y la Guerra de Argelia», Hispania, 81/269 (Madrid, 2021): 797-825. https://doi.org/10.3989/hispania.2021.021.

\section{INTRODUCCIÓN}

La trayectoria que José María de Areilza (1909-1998), conde consorte de Motrico, siguió en el lapso comprendido entre su asunción de la jefatura del secretariado político de don Juan de Borbón en 1966 hasta su retirada de la política activa en 1983 es de sobra conocida, a pesar de que aún no existe un estudio biográfico riguroso sobre el personaje. Su labor como ministro de Asuntos Exteriores en el primer Gobierno de la monarquía (1975-1976) ha sido objeto de estudio detallado en diversos trabajos historiográficos, además de haber sido relatada retrospectivamente por el propio Areilza².

Menos conocido y estudiado es, sin embargo, el extenso periodo en el que Areilza, que había ejercido de activo conspirador monárquico entre 1941 y $1943^{3}$, sirvió al régimen de Franco en calidad de embajador en Argentina (19471950), los Estados Unidos (1954-1960) y Francia (1960-1964). En efecto, no ha visto todavía la luz ninguna aproximación de índole académica que estudie monográficamente las diligencias llevadas a cabo por Areilza en París, Buenos

2 BASSOLS, 2007a: 211-233. OREJA AGUIRRE, 2011: 124-144. AREILZA, 1977

3 A la altura de 1943 Areilza había comprendido que el derrocamiento de Franco resultaba inviable, propugnando abiertamente la colaboración con el régimen. AREILZA, 11-12 (1943): 67-68. 
Aires o Washington. La inaccesibilidad de sus papeles personales y la dificultad que supone realizar cualquier búsqueda concienzuda en el fondo documental del Ministerio de Asuntos Exteriores, custodiado en el Archivo General de la Administración (AGA) y desprovisto aún de inventario, podrían explicar la preterición a la que ha sido objeto la figura del conde de Motrico en los estudios de índole académica sobre el régimen de Franco y su política exterior.

No obstante, las referencias a la labor diplomática de Areilza en Francia realizadas por la profesora Esther Sánchez ${ }^{4}$ y el testimonio retrospectivo de Areilza en sus Memorias exteriores ${ }^{5}$, unidos a los documentos que ha sido posible localizar tanto en el AGA como en el Archivo de la Fundación Nacional Francisco Franco (AFNFF) y en otros fondos documentales de carácter privado, permiten realizar una aproximación a las gestiones que Motrico realizó durante su periodo como embajador en París. Diligencias cuyo objetivo era evitar que España, a ojos de las autoridades francesas, apareciera como alineada con los detractores del presidente De Gaulle y de su política de autodeterminación para Argelia. Un territorio que, a diferencia de Marruecos o de Túnez, pertenecía administrativamente a la Francia metropolitana ${ }^{6}$, y entre cuya población se contaba alrededor de un millón y medio de colonos de origen europeo. Allí el Ejército francés llevaba seis años librando una sangrienta guerra contra los nacionalistas argelinos del Frente de Liberación Nacional (FLN). Existen indicios de que el FLN recibió armamento, al menos hasta 1961, enviado clandestinamente desde España con la anuencia de altas autoridades del régimen franquista ${ }^{7}$, el cual se mostró proclive a los rebeldes argelinos hasta el advenimiento de la V República ${ }^{8}$. El conflicto que enfrentaba a los defensores de la política gubernamental sobre Argelia con los partidarios de la Algerie Française llegó al paroxismo precisamente en $1960^{9}$, año de la llegada

4 SÁNCHEZ, 2006.

5 AREILZA, 1984.

${ }^{6}$ En 1960 Argelia estaba dividida en quince departamentos, la principal unidad administrativa existente en la Francia metropolitana, trece de los cuales se ubicaban en la franja costera septentrional, mientras que los dos restantes comprendían, en el sur, el vasto territorio desértico del Sáhara.

${ }^{7}$ Cembrero, Ignacio, «El doble juego de Franco en la guerra de Argelia», El País, Madrid, 31/10/2004.

${ }^{8}$ En 1956 Franco declaró que «España aportaría su ayuda a los pueblos de África del norte a fin de consolidar su independencia». Asimismo, en los medios militares y diplomáticos se conocían las frecuentes visitas que los líderes del FLN realizaban a España y a la antigua zona del Protectorado español en Marruecos con el fin de recabar apoyos a la causa de la independencia argelina. El Gobierno francés amenazó con dificultar las futuras relaciones con España «si no se detenían inmediatamente los devaneos de ciertas autoridades españolas con los rebeldes argelinos». YBARRA ENRÍQUEZ DE LA ORDEN, 2010: 150. Acerca de la connivencia española con los nacionalistas argelinos véase también DULPHY, 2005: 2-3.

9 HORNE, 2006: 415. 
de Areilza a París, sumiéndose entonces Francia en una profunda crisis interna que, además de poner en grave peligro la continuidad del general De Gaulle en la jefatura del Estado, obstaculizaba la plena normalización de las relaciones con España. La simpatía que ciertos sectores del régimen español mostraban por los civiles y militares opuestos a la autodeterminación de Argelia sería otra de las dificultades a la que el embajador español, resuelto como estaba a contribuir a la forja de un vínculo de sincera cooperación entre los dos países, debió hacer frente durante su misión diplomática en la capital francesa. Misión a la que, voluntariamente, pondría fin en octubre de 1964, distanciándose definitivamente del régimen político surgido de la guerra civil española, al cual había servido en el exterior durante trece años.

\section{España ante la Francia del general de Gaulle}

Areilza asumía el puesto de embajador de España en París reemplazando a José Rojas y Moreno, conde de Casa Rojas, y coincidiendo con un indiscutible mejoramiento de las relaciones franco-españolas, el cual había comenzado en 1957 merced a la colaboración militar de ambos países en la Guerra de IfniSáhara (1957-1958), para intensificarse una vez consumado el retorno del general Charles de Gaulle al poder un año después. Designado en primer lugar jefe de gobierno por la Asamblea Nacional en 1958, elevado a la jefatura del Estado poco después, y fundador de un régimen semipresidencialista, la V República, De Gaulle intensificó decididamente el acercamiento a la España de Franco, movido tanto por consideraciones de realpolitik como por una cierta afinidad con los valores y principios conservadores que informaban el régimen español, sin olvidar el interés pragmático de defender los intereses económicos de Francia $^{10}$ ni la voluntad de contrarrestar la influencia de las potencias anglosajonas en el continente europeo ${ }^{11}$. Cuestión esta última que ofrecía enormes posibilidades a España y a su diplomacia, puesto que la política exterior gaullista se orientaría hasta 1969 a la prosecución de la grandeur en el seno de una «Europa de las patrias», fundamentada ésta en la cooperación intergubernamental, y destinada a liberar a Francia de la tutela estadounidense y a dotarla de plena capacidad para participar en el diálogo este-oeste ${ }^{12}$.

Desde el punto de vista español, y en concreto, a juicio del Ministerio de Asuntos Exteriores, la coyuntura existente en julio de 1960 permitía no solamente profundizar en el estrechamiento de las relaciones con el vecino del norte, sino emplear la robustecida interlocución con París, que había apoyado

10 MORAVCSIK, 1998: 4 y ss.

11 SÁNCHEZ, 2004: 115.

12 SÁNCHEZ, 2006: 44. 
la entrada de España en la Organización Europea para la Cooperación Económica (OECE), para propiciar la paulatina incorporación del país al proceso de integración europea. Fernando María Castiella entendió que su viejo amigo Areilza $^{13}$, quien había coincidido en Washington con el ministro de Asuntos Extranjeros de De Gaulle, Maurice Couve de Murville, durante el tiempo en que este sirvió como embajador de Francia en los Estados Unidos, era el hombre idóneo para sacar todo el partido a la prometedora relación bilateral con la V República Francesa. Franco mismo manifestaría privadamente, en diciembre de 1959, que Motrico le parecía «un buen embajador», dotado de «muchas cualidades buenas $\rangle^{14}$. Con el nombramiento de Areilza, Franco, además de poner de manifiesto su apoyo a las proclividades europeístas del Palacio de Santa $\mathrm{Cruz}^{15}$, realizaba una concesión a los monárquicos y al conde de Barcelona, cuya afinidad con Motrico el jefe del Estado conocía perfectamente ${ }^{16}$. Resulta harto revelador que un busto del rey Alfonso XIII acompañase al retrato de Franco en el salón principal de la embajada durante los cuatros años en que Areilza permaneció en París ${ }^{17}$.

Sin embargo, la cordialidad política que París mostraba con el régimen franquista, nunca se tradujo en un apoyo explícito y real en aquellos foros, como la OTAN y el Mercado Común ${ }^{18}$, a los que el régimen español deseaba incorporarse para avanzar en su rehabilitación internacional y consolidar el viraje económico iniciado en virtud del Plan de Estabilización ${ }^{19}$. Asimismo, la creación de una genuina alianza con Francia, que se sustanciara en una estrecha colaboración en materia política, económica y de defensa, que Areilza propugnó con ahínco desde París ${ }^{20}$, no gozó del respaldo del Gobierno español. Este, temeroso de que una hipotética alianza hispano-francesa derivase en una relación desigual con el país vecino ${ }^{21}$, ni siquiera la empleó como baza en las arduas negociaciones para la renovación de los acuerdos con Estados Unidos en 1963.

13 Veinte años antes, Areilza y Castiella habían escrito juntos el libro Reivindicaciones de España (1941). En él se recogían las principales reclamaciones territoriales planteadas por la España de Franco. Entre los territorios reivindicados se encontraba el Oranesado. AREILZA y CASTIELLA, 1941: 213.

${ }^{14}$ FRANCO SALGADO-ARAUJO, 1976: 273.

15 Véase BASSOLS, 2007a: 205-236; 2007b: 219-242. También PARDO, 1996: 225-239.

16 SUÁREZ, 1984: 209.

17 Pérez Ferrero, Miguel, «Brillante ejecutoria diplomática de don José María de Areilza», $A B C$, Madrid, 2/10/1964.

18 PARDO, 2008: 122.

19 SÁNCHEZ, 2004: 122.

${ }^{20}$ Carta de Areilza a Castiella, n. ${ }^{\circ}$ 205, París, 19/6/1962, AFNFF, documento 22801.

${ }^{21}$ Encuadramiento político de la visita de Couve de Murville, AGA, caja 82/20926, exp.1. 


\section{LAS PRIMERAS GESTIONES}

El 28 de julio de 1960, inmediatamente después de presentar las cartas credenciales al general De Gaulle, Areilza ofreció una extensa rueda de prensa en la que, interpelado acerca del impacto que iba a tener en su misión la Guerra de Argelia, expresó su deseo de que se alcanzase un entendimiento entre las partes en el que se reconociera equitativamente lo mucho que África debía a Europa. El nuevo embajador no dudó en calificar al Viejo Mundo como alma mater de los territorios situados en la orilla sur del Mediterráneo.

Aunque el conflicto de Argelia apenas sí se trató en la primera entrevista que Areilza mantuvo con el primer ministro y fiel colaborador del presidente De Gaulle, Michel Debré, celebrada en octubre en 1960, Areilza estaba al tanto para entonces del profundo malestar que la política de entendimiento con el FLN adoptada por el general De Gaulle estaba causando en amplios sectores del Ejército y de la clase política francesa. A pesar de que su retorno al poder había sido propiciado por los generales partidarios de la conservación a ultranza de una Argelia francesa y soslayando los equívocos mensajes que dirigió a los colonos franceses en 1958 (Je vous ai compris; Vive l'Algerie française!), De Gaulle había juzgado que no tenía otra alternativa que poner fin a la guerra y permitir la independencia de una Argelia asociada a Francia ${ }^{22}$. Sin embargo, la decisión de negociar con los rebeldes argelinos podía repercutir gravemente en las relaciones con España, pues un número considerable de políticos y militares implicados en la fallida rebelión de «las barricadas» de Argel, acontecida en enero de 1960, se habían refugiado en territorio español, donde habían reanudado sus actividades conspirativas.

A mediados de agosto de ese año, Areilza pasó unos días de descanso en España en los que aprovechó para entrevistarse con Franco y Castiella en San Sebastián y, en Madrid, con el capitán general Agustín Muñoz Grandes, jefe del Alto Estado Mayor. Esta estancia en la patria le permitió advertir que la larga y sangrienta guerra de Argelia había impactado hondamente en amplios sectores de las Fuerzas Armadas españolas y de los servicios de información. Asimismo, una parte de la prensa, movida por un antigaullismo visceral, tomaba abiertamente partido por la extrema derecha francesa y por la causa de la Algerie française ${ }^{23}$. En el transcurso de su entrevista y de acuerdo con el testimonio retrospectivo de Motrico, Franco le expresó su convencimiento de que el Ejército francés no podría imponerse a los rebeldes argelinos y de que la independencia de Argelia era el colofón inevitable a un Marruecos y a un Túnez emancipados. Una postura en absoluto coincidente con la que Franco manifestaría en octubre de 1960, cuando confió al jefe de su Secretaría Militar

${ }^{22}$ DE GAULLE, 1970: 89

${ }^{23}$ AREILZA, 1984: 147. 
que únicamente mediante las armas podía Francia conservar Argelia, pues los plebiscitos resultaban, en su opinión, contraproducentes ${ }^{24}$. En cualquier caso, a Areilza le constaba que el jefe del Estado no dejaba de recibir informes «intoxicadores» que tenían su origen en el aparato conspiratorio francés, fuertemente implantado en Argelia, que se caracterizaba por la difusión de noticias falsas sobre el desarrollo de la guerra ${ }^{25}$. Castiella quedó impresionado cuando Areilza le expuso las preocupantes informaciones que había recabado en suelo español, y no dudó en ratificar a su embajador la confianza absoluta que tenía en su misión, así como el respaldo de Franco y del Gobierno para mantener, dentro de la «debida neutralidad», una mínima lealtad al presidente De Gaulle y al Ejecutivo francés ${ }^{26}$. Una posición cuyo mantenimiento no iba a estar exento de dificultad, puesto que una parte considerable de la población europea de Argelia era de origen español, siendo además evidente que Ejército francés se mostraba poco dispuesto a transigir con las reivindicaciones de los nacionalistas argelinos. A ello se unía el hecho de que la política española a propósito de la descolonización de Argelia iba a ser inevitablemente observada con atención por los países árabes, así como por los Estados del Tercer Mundo que acababan de acceder a la independencia ${ }^{27}$.

De vuelta en París, en octubre de 1960 Areilza remitió una larga carta al ministro Castiella en la que daba cuenta de las profundas repercusiones que la Guerra de Argelia estaba teniendo en la política interior francesa, donde la izquierda y la derecha políticas se hallaban abiertamente enfrentadas en torno a la cuestión: «Argelia es hoy manzana de discordia entre partidos y grupos y piedra de toque de muchas cosas y ahí [en la política interior] es donde puede el conflicto argelino cristalizar impensadamente en un episodio de grave trascendencia política y militar». En su misiva, el embajador español se mostraba convencido de que el auténtico líder del movimiento conspiratorio era Raoul Salan, «el más frío, astuto y prudente de los generales "argelinos"», el cual estaba colocando las distintas piezas en cada sitio para utilizarlas cuando llegase el momento oportuno. Según exponía Areilza, dicha oportunidad podía llegar muy pronto, quizá en apenas unos meses, «si las fuerzas en presencia siguen encadenadas a su proceso lógico y empujadas como ahora por vendavales de pasión e intereses poderosos, internos y externos $\rangle^{28}$.

El 14 de octubre de 1960, Motrico complementó la información anterior revelando que la situación en el seno del Ejército francés era «tensa», pues a la hostilidad que hacia la política argelina de De Gaulle profesaba una parte

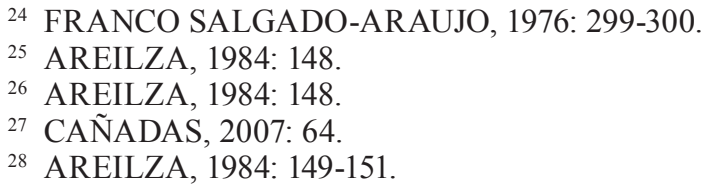

25 AREILZA, 1984: 148.

26 AREILZA, 1984: 148.

${ }^{27}$ CAÑADAS, 2007: 64.

28 AREILZA, 1984: 149-151. 
del Ejército destinado en Argel, se unía en aquel momento la animosidad de elementos claves del Ejército metropolitano. Dichos grupos, de acuerdo con las informaciones recabadas por Motrico, también se oponían al proyecto del presidente de dotar a Francia con una force de frappe o fuerza de disuasión nuclear. En cualquier caso, lo más relevante de lo averiguado por Areilza era que dicho malestar se había extendido, presuntamente, al alto mando estadounidense y a las fuerzas de ese país estacionadas en Francia, que deploraban la adopción de una política tan «poco atlántica»" ${ }^{29}$.

Apenas cuatro días después de transmitir esta inquietante información al Ministerio de Asuntos Exteriores, y valiéndose de las gestiones de un amigo común de nacionalidad española, Areilza tuvo ocasión de reunirse con el general Salan, comandante en jefe de las fuerzas francesas en Argelia entre 1956 y 1958 y el militar más distinguido de Francia ${ }^{30}$. «Ni gaullista ni petainista» durante la Segunda Guerra Mundial, simplemente «antialemán», ningún soldado francés de su generación había combatido tanto como él ${ }^{31}$. De Gaulle, pese a admitir que Salan era un personaje capaz, hábil y atractivo, resolvió relevarlo del mando de las fuerzas en Argelia al advertir en él «un no sé qué de tornadizo y enigmático que me parecía cuadrar muy mal con lo que una gran y recta responsabilidad exige de certidumbre y derechura $\iota^{32}$. Significativamente, poco antes de su relevo Salan había declarado en un discurso que «para nosotros el Mediterráneo atraviesa Francia como el Sena atraviesa París $»^{33}$, postura que compartía la inmensa mayoría de la población europea de Argelia ${ }^{34}$. De acuerdo con el relato de la entrevista que Areilza transmitió a Madrid, Salan, en primer lugar, expresó su admiración tanto por la personalidad de Franco como por la manera admirable en que este supo conducir «nuestra guerra de liberación», y hacer frente después a las más complicadas circunstancias internacionales. Una vez entrados en materia, Salan se mostró convencido de que ni los colonos y residentes franceses, como tampoco la población de origen español que habitaba la zona de Orán, aceptarían jamás ni la independencia

${ }^{29}$ Carta de Areilza a Castiella, n. ${ }^{\circ}$ 15, París, 14/10/1960, AGA, caja 82/20925, exp. 4.

${ }^{30}$ Carta de Areilza a Castiella, n..$^{\circ}$ 21, París, 18/10/1960, AGA, caja 82/20925, exp. 4. Salan abordará su ruptura con De Gaulle y las razones de su defensa a ultranza de la Argelia francesa en el último volumen de sus memorias, tituladas El fin de un imperio. SALAN, 1974.

${ }^{31}$ HORNE, 2006: 178.

32 DE GAULLE, 1970: 66.

33 SALAN, 1974: 316.

${ }^{34}$ Durante un viaje oficial a Argelia, realizado entre octubre y noviembre de 1959, el conde de Casa Rojas pudo comprobar que la población de origen europeo era intransigente en cuanto a la permanencia de Francia en aquel territorio: «Algunos de los españoles con los que hablé en Argelia me dijeron que, si Francia abandonaba el país, ellos se echarían al monte para defender sus intereses». Despacho del conde de Casa Rojas, n. ${ }^{\circ}$ 2081, París, 4/11/1959, AFNFF, documento 22393. 
ni las fórmulas de «Argelia argelina» planteadas por De Gaulle. En opinión de Salan, cuando los rebeldes tratasen de ejercer presión sobre ellos, los colonos, en último término, se defenderían por sus propios medios, creando una situación insostenible de guerra civil. Salan insistió en que el Ejército tampoco aceptaría nunca una salida de Argelia que supusiera la entrega del territorio, convertido en Estado independiente, al FLN: «Para ello estamos de acuerdo los mandos, de coronel para arriba, y también una gran mayoría de los oficiales jóvenes, que son quienes llevan el peso de la campaña, con un nutrido y doloroso porcentaje de bajas». El Ejército, advirtió el militar francés a Motrico, no iba a tolerar ni la alteración traumática de la vida nacional ni el advenimiento de un gobierno de izquierdas o de frente popular dispuesto a negociar una paz inmediata con los rebeldes argelinos. Salan negaba que hubiese conspiración alguna; lo que existía era una decidida voluntad en el Ejército «de no dejarse arrebatar la victoria y a no asistir pasivamente a la entrega del poder por culpa de los sucesos de Argelia, a una facción de izquierdistas que llevaría a Francia al borde del comunismo y negociaría a cualquier precio la paz con los rebeldes». Las elocuentes palabras del general despejaron cualquier duda que Areilza pudiese haber abrigado acerca de la disposición de Salan a encabezar una sublevación en Argelia, en la Francia metropolitana o en ambas. El embajador interpretó asimismo que era deseo de Salan que transmitiese al Gobierno español la firme disposición de numerosos jefes y oficiales franceses a recurrir a la fuerza para impedir la independencia de Argelia ${ }^{35}$.

Solamente había transcurrido una semana desde la entrevista cuando Salan pronunció una explosiva rueda de prensa en la que declaró la guerra total al presidente De Gaulle y en la que anunció que asumía oficialmente la jefatura del movimiento por una Argelia francesa. No obstante, el general rebelde era consciente que, dada la estrecha vigilancia a la que estaba sometido, le resultaría imposible encabezar una insurrección en la Francia metropolitana ${ }^{36}$. Por consiguiente, optó por evadirse a través de la frontera con España e instalarse inicialmente en San Sebastián, trasladándose posteriormente a Madrid. La noticia sobresaltó a Areilza, si bien desde Madrid le aseguraron que Salan estaría permanentemente vigilado a fin de conocer sus movimientos e impedir que pudiese alcanzar territorio argelino ${ }^{37}$. Empero, Muñoz Grandes reveló a Franco, en una nota fechada en diciembre de 1960, que dos amigos de Salan se aprestaban a viajar a la capital de España desde San Sebastián, con la misión de conseguir que el Gobierno español autorizase al general rebelde a desplazarse a Argelia ${ }^{38}$.

\footnotetext{
${ }^{35}$ AREILZA, 1984: 152.

36 HORNE, 2006: 420.

37 AREILZA, 1984: 155.

38 Nota de Muñoz Grandes a Franco, diciembre de 1960, AFNFF, documento 4140.
} 
El 3 de noviembre de 1960 Areilza escribió a Castiella mostrándose convencido de que la llegada clandestina de Salan a España no había sido motivo de sorpresa para el ministro. Asimismo, explicó que la intransigencia de Salan, así como su hostilidad al presidente De Gaulle, resultaban «chocantes» pues aquél, pese a ser un hombre oscuro y taimado, siempre había mostrado una actitud prudente y de gran cautela. Areilza se congratulaba, no obstante, de que la prensa francesa, con excepción de los periódicos de extrema izquierda, hubiese reaccionado a la huida de Salan de manera discreta y respetuosa hacia España. En cualquier caso, hacía notar Motrico, flotaba en el ambiente una duda razonable acerca de las razones de Salan para instalarse en España. Dado el incremento de la tensión en el conflicto argelino, provocado tanto por la pretensión del FLN de internacionalizarlo y la movilización de la izquierda francesa, por un lado, como por la política de resistencia a ultranza propugnada desde amplios sectores civiles y militares, por otro, Areilza sugería al ministro la conveniencia de observar los acontecimientos con calma y suma atención. Debía mantenerse el mayor número de contactos posible («cosa que vengo haciendo en la medida de mis fuerzas») y adoptar una actitud de gran prudencia y cautela ${ }^{39}$. Motrico estaba, por tanto, propugnando la adopción de una política de equidistancia y de neutralidad, que justificaba esgrimiendo el incierto resultado del inevitable e inminente choque de las fuerzas en oposición.

La sugerencia a Castiella estuvo sin duda motivada tanto por la información puntual y de primera mano que facilitaban a Areilza los cónsules españoles bajo su jurisdicción en Argelia ${ }^{40}$, como por las reveladoras entrevistas que el embajador había mantenido poco antes con Jacques Soustelle y Georges Bidault, ambos miembros destacados del Comité de Vincennes. Este grupo se había constituido en junio de 1960 y reunía a eminentes figuras políticas comprometidas con la causa de la Algerie française ${ }^{41}$. Se trataba, en palabras de Motrico, del «estado mayor civil» de la tesis de la Argelia francesa ${ }^{42}$.

El etnólogo e historiador Jacques Soustelle, fiel colaborador de De Gaulle durante años y gobernador general de Argelia entre 1955 y 1956, aseguró al embajador español que ni el millón y medio de residentes franceses (pieds noirs) ni los quinientos mil efectivos del Ejército francés en Argelia aceptarían nunca la solución independentista y que lucharían violentamente contra ella, sin atender a lo que decidiera el presidente de la República ${ }^{43}$.

${ }^{39}$ Carta de Areilza a Castiella n. ${ }^{\circ}$ 36, París, 3/11/1960, AGA, caja 82/20925, exp. 4.

${ }^{40}$ Con el visto bueno del Ministerio de Asuntos Exteriores, Areilza ordenó reforzar el servicio consular en Argelia y varios cónsules fueron llamados por él a París para que le facilitaran datos confidenciales. AREILZA, 1984: 155

${ }^{41}$ HORNE, 2006: 417.

${ }^{42}$ Carta de Areilza a Castiella n. $^{\circ}$ 36, París, 3/11/1960, AGA, caja 82/20925, exp. 4.

43 AREILZA, 1984: 152. 
En cuanto a Georges Bidault, fundador del democristiano Movimiento Republicano Popular (Mouvement Républicain Populaire, MRP) y varias veces ministro durante la IV República, manifestó ante Areilza que De Gaulle estaba aislado, rodeado de gentes miserables que lo adulaban y que ignoraba por completo la influencia que la Unión Soviética estaba ejerciendo en el movimiento independentista argelino. Bidault estaba convencido de que una Argelia independiente se convertiría irremediablemente en un bastión soviético en el Mediterráneo, lo cual, al quebrantar la estrategia de seguridad de Occidente, llevaría a la tercera guerra mundial. Asimismo, el político democristiano celebró que en España estuviese surgiendo una «fuerte corriente de opinión favorable» hacia los políticos y militares partidarios de una Argelia francesa, tendencia que juzgaba extraordinariamente oportuna dado que el año 1961 iba a ver el fin del régimen del general De Gaulle, «derribado por la violencia» ${ }^{44}$.

La situación se agravó en el mes de diciembre de 1960 y, coincidiendo con la visita del presidente De Gaulle a Argel con vistas al referéndum de autodeterminación previsto para enero, las fuerzas de seguridad españolas perdieron la pista a Salan temporalmente. Areilza se puso de inmediato en contacto con Ramón Sedó, a la sazón director general de Política Exterior, quien le aseguró que la policía lo buscaba activamente. La irónica respuesta de Motrico, temeroso de que Salan se aprestase a alcanzar territorio argelino, denotaba su profunda frustración: «Espero que por lo menos me comuniquéis cuándo saldrá del territorio español en avión para tomar el mando del levantamiento militar contra De Gaulle». Sea como fuere, el embajador hizo saber a diversos funcionarios del Quai d'Orsay que Salan no tardaría en ser localizado, consiguiendo disipar sus dudas «parcialmente»" ${ }^{45}$. Ese mismo mes de diciembre Muñoz Grandes trasladó a Franco que, según el testimonio de uno de los colaboradores de Salan, este no se podía «volver atrás», siendo la sublevación del Ejército francés, por tanto, inminente ${ }^{46}$.

\section{Peligro de sublevación militar}

Para entonces, Areilza ya se había entrevistado con el eminente político Edgar Faure, miembro del Partido Radical y varias veces primer ministro durante la IV República, quien mantenía una postura, según Motrico, de gau1 lismo «moderado». Durante su encuentro, Faure manifestó que el proceso de

${ }^{44}$ AREILZA, 1984: 153-154. Hallándose en el exilio, del que regresaría en 1968, Bidault publicaría sus memorias políticas, tituladas D'une resistance a l'autre. BIDAULT, 1965.

${ }^{45}$ AREILZA, 1984: 156. Carta de Areilza a Castiella, n. ${ }^{\circ}$ 64, París, 12/12/1960, AGA, caja 82/20925, exp. 4.

${ }^{46}$ Nota de Muñoz Grandes a Franco, diciembre de 1960, AFNFF, documento 4140. 
autodeterminación se había impuesto y que la «autonomía» del territorio resultaba inevitable. Sin embargo, una Argelia autónoma, o incluso independiente, no tenía, a su juicio, que ser forzosamente prosoviética, ni caótica ni antifrancesa. Faure se mostró convencido de que De Gaulle iba a hacer frente con éxito a la situación, puesto que gozaba de la confianza de buena parte de la población en la metrópoli. De Gaulle, en definitiva, había adoptado, según Faure, la única posición razonable, que no era otra que la de abrir la puerta a una consulta popular, dando al Ejército al mismo tiempo la satisfacción de que permanecería en Argelia hasta que el proceso de transición acabase, y privando, asimismo, al FLN del argumento según el cual el Gobierno francés jamás se avendría a la fórmula de la independencia ${ }^{47}$.

Significativa y momentáneamente tranquilizadora resultó, asimismo, la conversación mantenida a finales de noviembre de 1960 con Couve de Murvi1le, en la que el ministro francés hizo saber a Areilza que la presencia de Salan en España no generaba en el Gobierno francés una preocupación importante, pues entendía que el general rebelde «no tenía tantas cartas en la mano» como daba a entender. Couve ironizó sobre los contactos que Salan decía haber establecido con altas personalidades españolas, especialmente con el cuñado de Franco y antiguo ministro de la Gobernación y de Asuntos Exteriores, Ramón Serrano Suñer ${ }^{48}$, quien poco antes había publicado un artículo en $A B C$ abordando el conflicto argelino y solidarizándose con la postura del general. Según informó Areilza a Castiella, Couve se expresó en los siguientes términos: «No hace falta que me diga usted que este personaje político no representa el punto de vista de su Gobierno. Digamos que su importancia en la escena política española es comparable a la del general Salan en la de aquí» ${ }^{49}$.

La tranquilidad, sin embargo, no duró mucho tiempo. A comienzos del mes de diciembre, Areilza tuvo conocimiento de que dos destacadas figuras de la rebelión «de las barricadas», el diputado por Argel Pierre Lagaillarde, recientemente liberado por el tribunal que lo juzgaba, y el coronel Jean Gardes, jefe del servicio de información del Estado Mayor, acababan de cruzar clandestinamente la frontera con España. Motrico alertó a Madrid de que los individuos citados iban a tratar de establecer contacto con el general Salan para planear acciones inmediatas en Argelia coincidiendo con la visita del presidente De

${ }^{47}$ Carta de Areilza a Castiella n. ${ }^{\circ}$ 39, París 8/11/60. AGA, caja 82/20925, exp. 4.

48 Serrano Suñer no alude en sus memorias a Salan ni a la copiosa correspondencia que mantuvo con él. SERRANO SUÑER, 1977. Sí se refiere al general francés, aunque de manera muy breve y superficial, en un libro de conversaciones mantenidas con el filósofo Heleno Saña, limitándose a negar que financiase las actividades de Salan en España. SAÑA, 1981: 340-341.

${ }^{49}$ Carta de Areilza a Castiella, n. ${ }^{\circ}$ 51, París, 25/11/1960. El artículo en cuestión fue publicado en $A B C$ el 13 de noviembre de 1960, con el título "Claudicación de Europa». En 1981 Serrano admitiría que su acérrima defensa de la Algerie Française había sido un error. SAÑA, 1981: 340 . 
Gaulle a Argel, prevista como parte de la campaña del inminente referéndum ${ }^{50}$. Pese a que las fuentes de Areilza no lo mencionaban, en aquel momento alcanzaba también territorio español Jean-Jacques Susini, otro de los implicados en «las barricadas». Además, Motrico tuvo conocimiento, por conducto del embajador saliente de los Estados Unidos en París, Amory Houghton, que tanto el presidente Eisenhower como el presidente electo Kennedy estaban resueltos a apoyar la posición del general Gaulle en la cuestión argelina, pues ambos consideraban que se trataba de la mejor solución para poner fin a la guerra. Conflicto que, según Houghton, preocupaba enormemente al alto mando militar estadounidense por el quebranto que causaba a la posición militar francesa dentro del dispositivo de seguridad occidental. En Washington temían una intervención directa de la República Popular China en Argelia si el conflicto se prolongaba ${ }^{51}$.

El 9 de diciembre de 1960 Areilza estuvo en condiciones de informar a Madrid de que había estado a punto de producirse un golpe de Estado en Argelia y en la Francia metropolitana. De acuerdo con su informador, el abogado Tixier-Vignancour, activista de «Argelia francesa» y simpatizante de la dictadura española, al producirse la insurrección la jefatura del Ejército la habrían asumido el general Jacques Allard y el general Edmond Jouhaud, antiguo jefe del Estado Mayor del Aire, que se encontraba en Argelia desprovisto de mando. El complot debía iniciarse en el Oranesado, donde varias unidades se hallaban firmemente comprometidas con la insurrección. Al frente de las tropas y civiles rebeldes en Argelia se pondría Salan, que, como Lagaillarde, acudiría desde España junto al resto de procesados por el levantamiento «de las barricadas». En el último momento, por razones desconocidas, el proyecto de golpe fue abandonado. Sin embargo, Lagaillarde y sus compañeros no tuvieron conocimiento de la anulación del plan y procedieron a entrar en territorio español tal como estaba previsto. Ante la gravedad de la situación, Areilza sugería prudencia a Castiella, dada la división que existía en las Fuerzas Armadas francesas y ante el hecho incontrovertible de que el presidente De Gaulle contaba con el apoyo mayoritario de la opinión pública tanto en Francia como en el exterior $^{52}$. Profundamente perturbado por la revelación, que incluía la supuesta complicidad en el movimiento insurreccional de altas personalidades del régimen español, Areilza decidió discutir el asunto con el encargado de negocios de la Embajada de los Estados Unidos, el cual le confirmó la verosimilitud de un golpe inmediato, a la desesperada, en Argel encabezado por las unidades operativas del Ejército. Sin embargo, el diplomático estadounidense le trasladó su convencimiento de que el ejército francés desplegado en Alemania Occidental no se uniría a la sublevación y de que ésta, de producirse, sería muy mal

${ }^{50}$ Carta de Areilza a Castiella, n. ${ }^{\circ}$ 57, París, 5/11/1960 1960. AGA, caja 82/20925, exp. 4.

${ }^{51}$ Carta de Areilza a Castiella, n. ${ }^{\circ}$ 57, París, 5/11/1960 1960, AGA, caja 82/20925, exp. 4.

${ }^{52}$ Carta de Areilza a Castiella, n. ${ }^{\circ}$ 58, París, 6/11/1960, AGA, caja 82/20925, exp. 4. 
vista por el presidente electo Kennedy, que procedería a apoyar sin reservas a De Gaulle ${ }^{53}$. Los acontecimientos de abril de 1961 revelarían lo atinado de la información en poder de la legación estadounidense.

Relativamente tranquilizadora resultó, asimismo, la conversación que el embajador español mantuvo con el mariscal Alphonse Juin, oriundo de Argelia, quien le aseguró que el general Salan, al carecer de mando de fuerzas, difícilmente podía acaudillar una sublevación militar. Juin, que se deshizo en elogios hacia Franco y hacia la sublevación del 18 de julio de 1936, estaba convencido de que tanto la jerarquía militar como la unidad del Ejército francés se mantendrían incólumes: «Los generales de la República Francesa no se sublevan, porque su tradición democrática viene desde hace muchas décadas, y acatan disciplinadamente el poder civil». No obstante, el prestigioso militar entendía que De Gaulle se engañaba al considerar que una Argelia autónoma no rompería sus vínculos con Francia ${ }^{54}$.

A pesar del testimonio del mariscal, Areilza personalmente aprobaba la política descolonizadora adoptada por De Gaulle, juzgándola como «el único camino viable» para Francia en un artículo que publicaría, en agosto de 1961, en el Diario Vasco y en el que ocultaba su identidad empleando el pseudónimo de Paul de Frisson. A su juicio, el fervoroso nacionalismo francés que animaba a De Gaulle «no le había obnubilado el juicio ni detenido su reloj en horas del pasado» ${ }^{55}$.

Mas el ánimo insurreccional de un sector del Ejército francés y la presencia en España de varios conspiradores, donde contaban con el apoyo de ciertos sectores de los servicios de información, de algunos mandos militares e incluso de varios ministros ${ }^{56}$, no constituían el único motivo de preocupación para Motrico en diciembre de 1960. En efecto, a mediados de aquel mes informó a Madrid de que, según sus contactos, los exiliados españoles en Francia estaban deseando que Salan, Lagaillarde y sus camaradas radicados en suelo español lograsen salir para Argelia, pues creían que ello menoscabaría las relaciones hispano-francesas. Los exiliados españoles, Areilza explicó a Castiella, eran plenamente conscientes de que cualquier apoyo que se prestase a elementos opuestos al Gobierno francés haría perder terreno a España y a su dictadura en en el mundo occidental, donde el presidente De Gaulle gozaba de gran prestigio y cuya opinión pública le respaldaba en la resolución del complejo conflicto argelino ${ }^{57}$.

53 AREILZA, 1984: 157.

${ }^{54}$ Carta de Areilza a Castiella, n. ${ }^{\circ}$ 62, París, 9/11/1960, AGA, caja 82/20925, exp. 4.

55 De Frisson (pseudónimo de José María de Areilza), «El porvenir de Francia», El Diario Vasco, San Sebastián, 8/8/1961. La prosa de Areilza resulta inconfundible y él mismo admitiría en sus memorias haber empleado dicho pseudónimo, concebido como una broma al entonces director de Le Figaro, Pierre Brisson, en varios artículos publicados en aquel periódico durante el verano de 1961. AREILZA, 1985: 34-36.

56 CAÑADAS, 2007: 65.

${ }^{57}$ Carta de Areilza a Castiella n. ${ }^{0}$ 64, París, 12/12/1960, AGA, caja 82/20925, exp. 4. 
Sea como fuere, el embajador de Francia en España, Roland de Margerie, hizo saber personalmente a Areilza en París que el general De Gaulle estaba satisfecho de la actitud adoptada hasta ese momento por el Gobierno español, especialmente en los días cruciales de la visita presidencial a Argelia, cuando Madrid tomó las medidas oportunas para impedir la salida clandestina de Salan y demás refugiados para aquellas tierras. Según de Margerie, el presidente había calificado ante él como «leal» el comportamiento de las autoridades españolas, además de subrayar que el régimen de Franco había hecho «lo que se le ha pedido con todo interés $\rangle^{58}$.

En vísperas del crucial referéndum sobre la autodeterminación de Argelia, fijado para el 8 de enero de 1961, Areilza remitió una carta a Castiella en la que, por primera vez a juzgar por la documentación consultada, criticó abiertamente tanto a los partidarios de la Algerie française, especialmente a Salan, como los argumentos empleados por éstos para desacreditar al presidente de la República:

Como siempre sucede cuando una minoría razona como si estuviera sola en el mundo, confundiendo su pasión política con el bien público, todo es bueno para destruir al que piensa de manera distinta. Esa minoría no comprende que nadie puede tomarle [sic] en serio al decir que el Presidente de Francia tiene ideas comunistas y masónicas (valga el contraste), cuando tan público es el patriotismo del General De Gaulle, un carácter el menos apropiado a plegarse a consignas de partidos o de ligas masónicas, cuyos últimos discursos fueron un ataque violento contra el gobierno soviético ${ }^{59}$.

En cuanto a Salan, Areilza afirmaba que su trayectoria nunca le había parecido clara, por lo que había procedido a indagar sobre él. De acuerdo con las fuentes que había consultado, el embajador español estaba en condiciones de afirmar que el general rebelde pertenecía a la masonería y que nunca se había caracterizado por abrigar ideas conservadoras. Era un hombre carente de escrúpulos, que tenía a buena parte del Ejército francés en su contra y que, incluso, había contemporizado con el Vietminh durante la Guerra de Indochina. Asimismo, había apoyado el retorno al poder de De Gaulle, a quien despreciaba, en mayo de 1958, a regañadientes y en el último momento. Transcurridas algunas semanas, Motrico se permitió manifestar a Castiella su alarma ante el hecho de que las autoridades españolas continuasen dando crédito a Salan después de la reveladora información que había reunido sobre él. El general rebelde, sentenciaba Areilza, era el único militar francés que se negaba a obedecer órdenes. Además, el embajador español advertía de que la pasión de los bandos enfrentados sería aprovechada arteramente por los comunistas y sus

${ }^{58}$ Carta de Areilza a Castiella, n. ${ }^{\circ}$ 68, París, 19/12/1960, AGA, caja 82/20925, exp. 4.

${ }^{59}$ Carta de Areilza a Castiella, n. ${ }^{\circ}$ 75, París, 7/1/1961, AGA, caja 82/20925, exp. 4. 
compañeros de viaje para «enturbiar las aguas». Bajo ningún concepto debía caerse en su juego ${ }^{60}$.

La autodeterminación de Argelia propugnada por De Gaulle obtuvo un respaldo abrumadoramente mayoritario en el referéndum al que ya se ha hecho mención (75\% de los votos). Sin embargo, en Argelia, donde el «sí» se impuso con un porcentaje próximo al $70 \%$, la abstención fue notable, confirmándose de este modo el arraigo del FLN en las grandes ciudades, de modo que en rigor solamente un $55 \%$ de la población argelina (colonos europeos y musulmanes) con derecho a voto se pronunció a favor de la autodeterminación. Significativamente, en Argel, donde existía una nutrida presencia de pieds noirs, el «no» se impuso nada menos que con el $72 \%$ de los sufragios ${ }^{61}$, aunque, de acuerdo con el dictamen del cónsul español en Orán, José Luis López Schümmer, se trataba de un «no» amargo y desilusionado, expresado por una población europea a la que el FLN había arrebatado la iniciativa política definitivamente ${ }^{62}$. En febrero de 1961, Salan, Susini y Lagaillarde se reunieron en Madrid para crear una organización que, integrada por civiles y desertores del Ejército, unificase a los hasta entonces dispersos comandos contrarios a la autodeterminación de Argelia y continuase la lucha por la Algerie française mediante tácticas terroristas. De esta manera nacía la OAS (Organisation de l'Armée Secrète, Organización del Ejército Secreto), cuya presidencia y dirección asumía Salan, con Lagaillarde, asesorado por un comité central, inmediatamente por debajo de él en la jerarquía ${ }^{63}$. Especialmente activa en las ciudades de Argel y Orán, en menos de un año la OAS acabó con la vida de 2.360 personas en Argelia e hirió a más de 5.000. En Argel, sus sangrientas acciones causaron el triple de víctimas mortales que las que se cobró el FLN desde 1956 en adelante ${ }^{64}$.

Las inminentes conversaciones de paz con los rebeldes argelinos y las probables repercusiones regionales de la emancipación de Argelia fueron las principales cuestiones que Motrico abordó en el transcurso de un almuerzo con Louis Joxe, a quien De Gaulle había nombrado, en noviembre de 1960, ministro encargado de los Asuntos Argelinos. Areilza preguntó expresamente a su interlocutor acerca de la región del Sáhara, en la que Francia deseaba permanecer una vez tuviese lugar la autodeterminación de Argelia. Joxe respondió que París buscaría internacionalizar el problema mediante la asociación de los Estados limítrofes, lo que incluía a España a través del territorio de Río de Oro (Sáhara Español). Añadió que el embajador soviético en Francia, Serguei Vinogradov, le había hecho saber que Moscú estaba conforme, en principio, con la

${ }^{60}$ Carta de Areilza a Castiella, n. ${ }^{\circ}$ 81, París, 25/1/1961, AGA, caja 82/20925, exp. 4.

${ }^{61}$ HORNE, 2006: 435.

62 El referéndum en Argelia, Despacho n. ${ }^{\circ}$ 18, Orán, 10/1/1961, AFNFF, documento 6154.

${ }^{63}$ Novais, José Antonio, «La discreta vida del general en Madrid», El País, 8/7/1984.

${ }^{64}$ HORNE, 2006: 441 y 531. 
explotación internacional del Sáhara, siempre y cuando quedasen excluidos de ésta los Estados Unidos y la República Federal de Alemania. Obviando la realidad, el diplomático soviético, Areilza hizo notar a Castiella, seguía creyendo posible alejar a la Francia del general De Gaulle de la Alemania de Adenauer.

En cuanto a Marruecos, el ministro francés era de la opinión de que su joven rey, Hassan II, no se inclinaba demasiado hacia el África negra, lo cual debía ser aprovechado para crear una zona magrebí, separada del resto del continente, sometida a la explotación económica de un grupo amplio de naciones europeas y árabes. Postura que, según expuso Motrico a Castiella, encerraba un prejuicio racial «poco cristiano» además de basarse en una premisa falsa, pues tanto Nasser en Egipto como Bourguiba en Túnez aspiraban al liderazgo de un movimiento de signo tanto panárabe como panafricano. Areilza también discrepó del criterio de Joxe a propósito de la injerencia soviética en Marruecos, que su interlocutor juzgaba débil al entender que Moscú no deseaba inmiscuirse en países geográficamente alejados de su área de influencia. Consideraba el embajador español que Joxe, al igual que el influyente diplomático estadounidense George Kennan, era incapaz de advertir que la idiosincrasia rusa en nada se identificaba con la pequeña minoría comunista representada por el Kremlin. El pueblo ruso poseía, en efecto, un instintivo recelo al expansionismo que obedecía a su situación geográfica, pero no así la cúpula dirigente del país, la cual «jugaba profesionalmente al ajedrez político haciendo avanzar o retroceder sus peones» a conveniencia ${ }^{65}$.

Sea como fuere, ni la victoria del «sí» en el referéndum de enero ni la disposición del Gobierno francés a negociar con el FLN había rebajado la tensión en Argelia, al contrario. El 20 de abril de 1961 el aristócrata español José Luis de Vilallonga solicitó ver de inmediato al embajador Areilza, quien lo recibió fuera de la legación «para no crearle problemas de incomodidad». El visitante transmitió una información de inmensa trascendencia: un exiliado republicano le había confiado la noche anterior que se estaba planeando un atentado contra el general De Gaulle que se haría coincidir con una inminente sublevación de los generales en Argel. No se trataba de la primera conspiración para acabar con la vida de De Gaulle de la que tenía conocimiento la legación española. Ya en octubre de 1959 el conde Casa Rojas había informado al Palacio de Santa Cruz de la existencia de un complot urdido por oficiales izquierdistas para asesinar al presidente, bien en su residencia de Colombey-les-Deux-Églises, bien en el mismísimo Palacio del Elíseo ${ }^{66}$. En esta ocasión, al parecer, todos los conspiradores eran hostiles a la autodeterminación de Argelia y habían solicitado, sin éxito, la colaboración en el magnicidio de varios ex combatientes de

${ }^{65}$ Carta de Areilza a Castiella, n. ${ }^{\circ}$ 107, París, 17/3/1961, ARP.

${ }^{66}$ Nota $n .^{\circ} 3$ aneja la carta $n .^{\circ} 98$ de Casa Rojas a Castiella, 15/10/1959, AFNFF, documento 25017.

Hispania, 2021, vol. LXXXI, n. ${ }^{\circ}$ 269, septiembre-diciembre, págs. 797-825, ISSN: 0018-2141, e-ISSN: 1988-8368 https://doi.org/10.3989/hispania.2021.021 
la guerra de España. Temiendo que las comunicaciones telefónicas estuvieran intervenidas, Areilza resolvió recurrir a su esposa, la condesa de Motrico, para conseguir una discreta entrevista con el secretario general del Palacio del Elíseo, Étienne Burin des Roziers, que lo recibió de madrugada y a quien reveló todo lo referido al plan para atentar contra el presidente. Se alteraron dispositivos, horarios y desplazamientos, y se descubrió la realidad de la amenaza y de parte de la trama. Burin des Roziers no pudo sino manifestar a Areilza la gratitud del Gobierno francés: «No tengo palabras para calificar nuestro agradecimiento por su gesto en horas tan difíciles», dijo. «No habían previsto nuestros servicios especiales esa hipótesis, considerándola como improbable ${ }^{67}$. Manifestaciones de indudable lealtad como la que se acaba de referir contribuyeron a que Areilza se ganase la plena confianza del presidente De Gaulle ${ }^{68}$. Prueba de ello es que Areilza sería invitado a asistir, en abril de 1964, a un almuerzo íntimo en el Palacio del Elíseo, en el que el presidente francés le habló con total franqueza tanto de las reservas que abrigaba acerca de la disposición de los Estados Unidos a emplear armas nucleares en Europa en caso de agresión soviética, como de su firme voluntad de robustecer las relaciones con España y de apoyar el ingreso de España en el Mercado Común ${ }^{69}$. Asimismo, en octubre de 1964, horas antes de que Areilza regresara a España tras renunciar voluntariamente a su puesto, De Gaulle ofreció al embajador y a su esposa un almuerzo de despedida, al que asistieron una treintena de comensales, y en el que el presidente se refirió al homenajeado como el «artífice de la plena reconciliación de España y Francia, unidas por un destino común en la historia» $»^{70}$.

\section{Golpe de estado en Argel}

No obstante, las autoridades francesas no pudieron evitar que el sábado 22 de abril de 1961 las unidades militares destacadas en Argel se sublevaran ${ }^{71}$.

${ }^{67}$ AREILZA, 1984: 157-158. De Gaulle sobreviviría milagrosamente a dos atentados contra su vida perpetrados por la OAS, el primero de ellos, el 7 de septiembre de 1961 (detonándose un explosivo al paso de su coche) y, el segundo, el 22 de agosto de 1962, cuando su vehículo fue ametrallado por un comando terrorista encabezado por el coronel Jean-Baptiste Bastien-Thiry. FENBY, 2011: 475-476 y 493-496.

68 PERINAT, 1996: 117.

${ }^{69}$ Carta de Areilza a Franco, 9/4/1964, ARP.

70 «Areilza, artífice de la reconciliación hispano-francesa», $A B C, 29 / 10 / 1964$. También «El Presidente De Gaulle ofreció una comida de despedida a Areilza», Arriba, Madrid, 29 /10/1964.

${ }^{71}$ Poco antes de la consumación del golpe y por conducto de Serrano Suñer, Salan hizo llegar a Antonio de Oliveira Salazar una carta en la cual revelaba que se disponía a llevar a cabo «una acción dramática en nombre de la nación francesa» y que esperaba poder contar con el apoyo y comprensión del Gobierno portugués. RIBEIRO DE MENESES, 2009: 540. 
Nada más conocerse las primeras noticias del golpe, el Ministerio de Asuntos Extranjeros francés telefoneó a Areilza para conocer el paradero exacto del general Salan, a quien los sublevados esperaban en Argel para que asumiera la jefatura de la insurrección. Inmediatamente, el embajador español se puso en contacto con Castiella, el cual le aseguro que «no había que señalar novedad» a propósito de los partidarios de la Algerie française radicados en España. Acto seguido, Areilza, en cumplimiento de la orden expresa de Castiella, procedió a dar seguridades al Quai d'Orsay acerca del paradero de Salan, si bien, de acuerdo con su testimonio retrospectivo, lo hizo de mala gana porque conocía las «muchas y altas complicidades» con que los generales rebeldes contaban al otro lado de los Pirineos ${ }^{72}$. No obstante, en su largo informe sobre la delicada situación remitido al ministro ese mismo día, Motrico propugnaba de nuevo que el Gobierno español adoptase un «oportuno neutralismo» ${ }^{73}$. Veámoslo.

En primer lugar, Motrico hacía notar al ministro que la prensa francesa se había hecho eco del incremento de las medidas de seguridad y de vigilancia en torno a Salan y al resto de exiliados. Ello había causado una favorable impresión en los medios oficiales que contrastaba con la honda indignación de los partidarios de la Algerie française, alguno de los cuales había llegado a amenazar con represalias al embajador español por teléfono ${ }^{74}$. En cuanto a los exiliados españoles en suelo francés, habían reaccionado con contrariedad ante la negativa del Gobierno español a permitir el traslado de Salan a Argelia, pues sabían que semejante postura redundaba en beneficio de la imagen internacional del régimen de Franco, además de fortalecer los vínculos entre Madrid y París. Sea como fuere, ante la posibilidad real de que la sublevación triunfase y de que De Gaulle fuese derrocado, Areilza recomendaba que las autoridades españolas adoptasen una posición neutral. Dicho neutralismo coadyuvaría, en caso de victoria del golpe, a que Francia se aproximase aún más al régimen español, pues una vez conquistado el poder, Salan, Jouhaud y el resto de sublevados adoptarían una política de integración franco-argelina abiertamente contraria a la política de descolonización gradual preconizada por los Estados Unidos. Quedarían así, sostenía Areilza, aislados del exterior (al igual que Portugal) y se verían obligados a librar una guerra internacionalizada en el norte de África. No obstante, de fracasar la insurrección, la posición neutral de España también resultaría fecunda, pues merecería el agradecimiento del presidente De Gaulle, cuyo prestigio y autoridad dentro y fuera de Francia se verían extraordinariamente reforzados. Según el dictamen de Areilza, contar con el apoyo del fundador de la V República permitiría al régimen español nada menos que neutralizar a la izquierda, como demostraba la inquietud que

72 AREILZA, 1984: 158.

${ }^{73}$ Carta de Areilza a Castiella n. ${ }^{\circ}$ 115, París, 22/04/1961, AGA, caja 82/20925, exp. 4.

${ }^{74}$ Nota verbal n. ${ }^{\circ}$ 86, París, 28/2/1961, AGA, 54/11468, paquete 154. 
la firme actitud de Madrid generaba entre los exiliados españoles en Francia. En cualquiera de los dos casos, la neutralidad española, proclamaba Motrico, conferiría un enorme beneficio a la posición internacional de España:

La posición neutral de Su Excelencia puede llevarle a un triunfo diplomático extraordinario, porque ahora se presenta la oportunidad. Manteniendo el grueso del ejército en la península y estableciendo una buena relación con Marruecos, España volvería a ser tenida en cuenta en la estrategia occidental, ahora que Francia se encuentra debilitada al perder libertad de acción y en peligro de desembocar en una guerra civil, y con Portugal desgastando poco a poco su vitalidad en conflictos coloniales $^{75}$.

No obstante, ese mismo día 22 por la tarde Areilza se sobresaltó al conocer, a través de la radio, que el general Salan acababa de aterrizar en el aeropuerto Maison Blanche de Argel procedente de España, de cuyo territorio se había evadido de manera rocambolesca con la ayuda de sus partidarios españoles ${ }^{76}, \mathrm{y}$ que asumía el mando de la sublevación. El general Franco confesaría unos días más tarde que la huida de Salan le había «molestado muchísimo» y que no le había agradado el comportamiento de una parte de la policía española, responsabilizando expresamente a Ramón Serrano Suñer, cuyo hijo mayor condujo el vehículo que trasladó a Salan al aeropuerto de Barajas ${ }^{77}$, de haber facilitado la evasión del general francés ${ }^{78}$. Sea como fuere, en su testimonio retrospectivo, Motrico alude a una conversación telefónica mantenida un día después del golpe de Argel con Muñoz Grandes, en la que supuestamente hizo ver al jefe del Alto Estado Mayor que la sublevación estaba condenada al fracaso, al no haber sido secundada por ninguna unidad del Ejército metropolitano, y que Occidente en su conjunto, con el presidente Kennedy a la cabeza, apoyaban sin reservas a De Gaulle. El diálogo concluyó con Areilza exhortando a Muñoz Grandes a que transmitiera a Franco la necesidad de solidarizarse de inmediato con las autoridades francesas, «a fin de superar los disparates cometidos» $\rangle^{79}$. De acuerdo con el relato de Motrico, esta conversación tuvo lugar unas horas antes de que De Gaulle, resuelto a reducir la disidencia «sin componendas ni

${ }^{75}$ Carta de Areilza a Castiella n. ${ }^{\circ}$ 115, París, 22/4/1961, AGA, caja 82/20925, exp. 4.

${ }^{76}$ El 23 de abril de 1961 Salán burló el cerco policial en torno al hotel Princesa de Madrid, escapando junto a Susini por una ventana. El avión, pilotado por el comandante Carlos Teixedor, condenado posteriormente en Consejo de Guerra a diez meses de cárcel, despegó del aeropuerto de Barajas sin la autorización del jefe del aeropuerto. SEGURA VARELO, 2004: 189-193 y Novais, José Antonio, «La discreta vida del general en Madrid», El País, 8/8/1984.

77 SEGURA VARELO, 2004: 190.

${ }_{78}^{78}$ FRANCO SALGADO-ARAUJO, 1976: 318.

79 AREILZA, 1984: 159. 
demora $»^{80}$, compareciera ante los franceses para llamar a la resistencia frente a los que, desdeñosamente, calificó de «cuarterón de generales retirados».

Sin embargo, un día después, el 24 de abril, Areilza expuso a Castiella que los rebeldes podían triunfar siempre y cuando consiguiesen desplegar su potencia militar en la metrópoli, lo cual «no dejaría de impresionar a los anglosajones, siempre realistas», si bien el entonces teniente coronel Alfonso Armada, quien acababa de llegar a París desde Argel, le había informado de que los sublevados carecían de medios aéreos para alcanzar la Francia metropolitana ${ }^{81}$. Al mismo tiempo, el embajador español reiteraba al ministro que el presidente francés contaba con el respaldo mayoritario de la población y que la política de autodeterminación asumida por De Gaulle resultaba enteramente apropiada para las potencias anglosajonas ${ }^{82}$.

El discurso radiado y televisado pronunciado por De Gaulle, que tuvo un hondo efecto entre los reservistas y soldados de reemplazo destinados en Argelia, exhortados por el presidente a desobedecer a sus mandos rebeldes, contribuyó decisivamente al fracaso del golpe. El día 25 todo había acabado. No obstante, la fallida sublevación indujo a De Gaulle a abandonar toda esperanza de mantener a la Argelia autodeterminada en un régimen de asociación con Francia, como era su deseo. La quiebra de la unidad en el seno de las fuerzas militares destacadas en Argelia, así como la desmoralización de éstas, privaban al presidente francés del único medio para imponer dicho plan por la fuerza a los rebeldes argelinos ${ }^{83}$. Por su parte, Areilza calificará de tardíos, en sus Memorias exteriores, tanto el gesto del Gobierno español de impedir la salida hacia Argel en avión del activista radical de la Algerie française Joseph Ortiz como el comunicado emitido por el Palacio de Santa Cruz, en el que se manifestaba el deseo de colaborar con las autoridades francesas y se admitía la «negligencia y demora en transmitir las órdenes de vigilancia» sobre Salan y Lagaillarde ${ }^{84}$. Sin embargo, en Así los he visto, obra publicada una década antes, había admitido que la «lealtad del Gobierno de Madrid en las horas decisivas» había contribuido a eliminar los recelos antifranquistas residuales abrigados por el presidente De Gaulle ${ }^{85}$. En efecto, sofocada la insurrección, Couve de Murville telefoneó a Areilza para transmitirle que comprendía los problemas que la presencia de Salan había causado a las autoridades españolas y que aceptaba plenamente las disculpas ofrecidas por el Ministerio de

${ }^{80}$ DE GAULLE, 1970: 126.

${ }^{81}$ Según sostiene Alistair Horne, el plan ideado por el general rebelde Maurice Challe jamás contempló la conquista del territorio metropolitano. HORNE, 2006: 456.

${ }^{82}$ Carta de Areilza a Castiella n. ${ }^{\circ}$ 116, París, 24/4/1961, AGA, caja 82/20925, exp. 4.

83 HORNE, 2006: 463.

${ }^{84}$ AREILZA, 1984: 160.

85 AREILZA, 1974: 308. 
Asuntos Exteriores, haciendo la siguiente y elocuente confidencia al embajador de España: «Sabemos con cuanta lealtad y eficacia se ha movido usted en estas horas decisivas. El general [De Gaulle] me encarga le transmita su personal agradecimiento ${ }^{86}$.

\section{QUID PRO QUO EN TORNO A LOS CONSPIRADORES DE AMBOS PAÍSES}

Sea como fuere, y a pesar de la actitud comprensiva adoptada por las autoridades francesas, inmediatamente después del golpe de abril, la presencia de antigaullistas radicales en territorio español continuaba siendo un motivo de inquietud para París. A finales de septiembre de 1961, Couve de Murville hizo saber a Areilza que el Gobierno francés tenía constancia de que la OAS planeaba asesinar al presidente De Gaulle como preludio a una nueva sublevación en Argelia ${ }^{87}$. De acuerdo con la información gubernamental, que Motrico corroboraba, la operación se había planeado en Madrid, donde los ex coroneles Antoine Argoud, Charles Lacheroy y Joseph Broizat mantenían un «estado mayor revolucionario». Colaboraban en el empeño de eliminar físicamente a De Gaulle Joseph Ortiz, residente en Mallorca, así como Lagaillarde. Couve solicitó a Areilza que transmitiera al Gobierno español la petición de que contra esos cinco individuos se tomaran medidas inmediatas, que podrían consistir en una residencia forzosa vigilada destinada a controlar sus movimientos y evitar la consumación del magnicidio. Dada la gravedad de la amenaza, el ministro francés esperaba que las autoridades españolas atendiesen el ruego del Gobierno francés, que, asimismo, era una petición personal del general De Gaulle al general Franco. Areilza respondió que, en su reciente visita a Madrid, había tenido ocasión de exponer tanto al ministro Castiella como al jefe del Estado español los inconvenientes que en las cordiales relaciones hispano-francesas generaba la presencia de los conspiradores antigaullistas en territorio patrio. No obstante, a renglón seguido añadió que a fin de que el Gobierno español pudiera satisfacer la petición francesa resultaba necesario que, sin mengua del respeto de los deberes de hospitalidad, ambos países se comprometieran a no tolerar en su territorio actividades subversivas o revolucionarias encaminadas a crear incidentes, perturbación o actos de violencia de cualquier clase en el territorio del otro. Es decir, España intensificaría el control sobre los exiliados franceses en España a cambio de que las autoridades francesas se comprometieran a vigilar estrechamente las actividades antifranquistas de los opositores españoles radicados al norte de los Pirineos. El ministro francés recordó entonces que su Gobierno ya se había comprometido por escrito, a comienzos

${ }^{86}$ AREILZA, 1984: 160.

${ }^{87}$ Carta de Areilza a Castiella, París, 30/9/1961, AFNFF, documento 22646. 
de 1961, a hacer lo necesario para evitar que en territorio francés se llevasen a cabo actos encaminados a crear perturbaciones o subversiones violentas en España. Compromiso que las autoridades francesas cumplieron escrupulosamente $^{88}$. Así, en el otoño de 1963, Areilza informaría con satisfacción a Castiella de que las actividades de los opositores españoles en territorio francés, que el régimen de Franco juzgaba como un grave obstáculo a la normalización de las relaciones hispano-francesas ${ }^{89}$, habían quedado reducidas a la mínima expresión ${ }^{90}$. Significativamente, en ninguno de sus volúmenes de memorias hace Areilza mención alguna a las gestiones llevadas a cabo cerca de las autoridades francesas para que éstas intensificaran la represión de los opositores españoles.

En cualquier caso, el tono empleado por Couve en 1961 y la inquietud que denotaban sus palabras demostraban, según hizo ver Areilza a Castiella, que la amenaza contra la vida del presidente francés era seria e inminente, y que el ruego formulado por De Gaulle no obedecía al interés de restringir las actividades de unos enemigos políticos, sino a una honda y perentoria preocupación. Además, Areilza se hallaba ahora convencido de que, si triunfaban los golpistas y De Gaulle desaparecía de escena, el poder no recaería en una junta militar derechista, sino en un cartel de izquierdas, incluso en un nuevo Frente Popular. Prueba de que los «rabadanes» se aprestaban a ese último escenario era, según sostenía el embajador, una reciente entrevista entre dos prohombres de la fenecida IV República: el radical Pierre Mendès-France y el socialista Guy Mollet. Por tanto, y a pesar de la gravedad de la situación, Areilza señaló a Castiella que existía una excelente oportunidad de generar en el Gobierno francés good will hacia España y el régimen franquista, que vería con satisfacción un incremento de la vigilancia sobre los antigaullistas, medida que además no resultaba «demasiado grave ni hiriente para los interesados» $»^{91}$. En marzo de 1962, poco antes de la conclusión de los acuerdos de Evian, Motrico manifestaría a Castiella que las autoridades españolas debían mostrar sincera comprensión por el drama que estaba viviendo el pueblo francés, es decir, la independencia de Argelia, por las hondas divisiones que la cuestión había generado tanto en la sociedad como en las Fuerzas Armadas francesas, y por las múltiples víctimas causadas por la actividad terrorista de la OAS. De esta manera, España se aseguraría el agradecimiento futuro e imprescindible de una Francia, que, junto con Alemania, constituía la base de la fortaleza europea, y cuyo apoyo diplomático resultaba indispensable, máxime cuando apenas había transcurrido un

${ }^{88}$ DULPHY, 2005: 10.

${ }^{89}$ Informe del Ministerio de Asuntos Exteriores, Índice de cuestiones en que Francia mantiene una actitud contraria a España, 9/5/1959, AGA, caja 82/20926, exp.1.

${ }^{90}$ La emigración española, despacho n..$^{\circ}$ 2185, París, 6/11/1963, AGA, caja 82/20926, exp.1.

${ }^{91}$ Carta de Areilza a Castiella, París, 30/9/1961, AFNFF, documento 22646. 
mes de la entrega de la carta en la que Castiella solicitaba la apertura de negociaciones con vistas a la deseada asociación de España al Mercado Común ${ }^{92}$.

\section{LOS ACUERdos de Evian}

Las negociaciones entre el Gobierno francés y el Gobierno Provisional de la República Argelina (GPRA) culminaron el 18 de marzo de 1962 con la firma de los acuerdos de Evian. Un mes antes, Areilza había conversado con el ministro de Asuntos Argelinos y jefe de la delegación francesa en las negociaciones, Joxe, acerca de las garantías que habrían de concederse a la minoría española radicada en Argelia. Joxe, a quien Motrico entregó una nota sobre el particular elaborada a partir de los informes que le había facilitado Ramón Sedó, se comprometió a velar por los intereses de los colonos españoles en unas negociaciones que, en cualquier caso, para entonces se hallaban muy avanzadas ${ }^{93}$. Tres días después de la firma de los acuerdos, Areilza entregó a Couve de Murville una carta de Castiella dirigida a De Gaulle, en la que el ministro español felicitaba cordialmente al presidente francés por el fin de las hostilidades en Arge$\mathrm{lia}^{94}$. El encuentro entre Areilza y el jefe de la diplomacia francesa asimismo se prestó a un intercambio de impresiones acerca de las encuestas de opinión realizadas con vistas al referéndum sobre los acuerdos de Evian, las cuales auguraban que éstos obtendrían una aplastante ratificación popular ${ }^{95}$. Así fue, en efecto, a pesar de que tanto el FLN como la OAS incumplieron el cese de hostilidades al que se habían comprometido ${ }^{96}$. Los acuerdos, que satisfacían la práctica totalidad de los objetivos de guerra fijados por el FLN en 1956 y consagraban el acceso a la independencia total y completa del territorio argelino, obtuvieron el «sí» del $90 \%$ del cuerpo electoral en la Francia metropolitana. El 1 de julio Argelia celebró su propio referéndum, registrándose casi seis millones de votos afirmativos y tan solo 10.000 votos en contra. Éstos últimos suponían el $10 \%$ del cuerpo electoral argelino y correspondían casi íntegramente a pieds noirs. Dos días después, el presidente De Gaulle reconoció la independencia de Argelia ${ }^{97}$, la cual no devendría un Estado satélite de la Unión Soviética, decantándose en cambio por el no alineamiento, si bien Moscú sería su principal suministrador de armamento durante tres décadas. En cuanto a los colonos de origen español, iniciaron inmediatamente después de

${ }_{92}$ Carta de Areilza a Castiella, n. ${ }^{\circ}$ 192, París, 8/3/1962, AGA, caja 82/17110.

${ }_{93}$ Carta de Areilza a Ramón Sedó, París, 7/2/1962, AGA, caja 82/20925, exp. 4.

${ }_{94}$ Carta de Areilza a Castiella, n. ${ }^{\circ}$ 193, París, 22/3/1962, AFNFF, documento 23854.

${ }_{95}$ Carta de Areilza a Castiella, n. ${ }^{\circ}$ 193, París, 22/3/1962, AFNFF, documento 23854.

96 Telegrama recibido de Orán, 10/5/1962, AFNFF, documento 23062.

97 HORNE, 2006: 522-531. 
la ratificación de los acuerdos, al igual que el resto de pieds noirs y con objeto de salvar la vida, un éxodo masivo que llevó a 50.000 de ellos a instalarse en la provincia de Alicante ${ }^{98}$. Areilza solicitó autorización al Gobierno francés para que España destacase medios navales y aéreos para evacuarlos, petición que fue sorprendentemente denegada ${ }^{99}$. La razón de la negativa de De Gaulle, quien ordenó expresamente al máximo responsable militar en Orán, el general Joseph Katz, que impidiera cualquier evacuación, acaso fue el interés por evitar el establecimiento de un exilio hostil en España. No obstante, el Gobierno español hizo caso omiso de la decisión adoptada por París y envío dos transbordadores a Orán, los cuales trasladaron a Alicante a más de 2.000 personas en la noche del 29 de junio de 1962, a las que se unirían decenas de miles más en el transcurso de aquel verano ${ }^{100}$. «La pesadilla», escribirá Areilza en 1984, «había terminado» ${ }^{101}$. De Gaulle y Francia se habían desembarazado del problema argelino de una vez por todas, si bien la OAS, provista aún de campos de entrenamiento y formación clandestinos en suelo español, proseguiría su actividad terrorista en el hexágono durante varios meses, llegando a perpetrar un atentado contra el jefe de Estado francés en agosto de 1962 que, por muy poco, no resultó mortal ${ }^{102}$.

Mas el problema de la plena legitimación internacional del régimen español $\mathrm{y}$, concretamente, de la aproximación a las Comunidades Europeas, subsistiría. Apenas había transcurrido un mes de la proclamación de la independencia argelina cuando Areilza redactó un informe en el que abogaba por la introducción de reformas políticas que permitieran mejorar la imagen exterior de la dictadura y propiciar su evolución en sentido liberal y democrático ${ }^{103}$. Reformas que ni Franco ni su fiel colaborador Luis Carrero Blanco estaban dispuestos a promover. De acuerdo con el testimonio retrospectivo de Areilza, fue la ausencia de voluntad aperturista en el seno del régimen franquista, unida al castigo a los participantes en el Congreso de Múnich en 1962 y la ejecución del dirigente comunista Julián Grimau un año más tarde, el principal motivo que le indujo a renunciar a su puesto de embajador y a asumir, al cabo de dos años, la jefatura del secretariado político del conde de Barcelona. Mediado el año 1964 se había convencido de que «el cierre deliberado del sistema político español iba a llevar al establecimiento de una radical incongruencia con el conjunto de principios que informaban la vida pública del resto de Europa $»^{104}$.

98 SEMPERE, 1997.

99 SEGURA VARELO, 2004: 253.

${ }^{100}$ SEGURA VARELO, 2004: 260. También SEMPERE, 1997: 58.

101 AREILZA, 1984: 160.

102 DEL PINO, 2012: 27.

103 Nota sobre la Unión Política Europea, San Sebastián, 7/8/1962, citada en CRESPO MACLENNAN, 2004: 89-90.

104 AREILZA, 1984: 186. 


\section{Conclusiones}

La designación, en 1960, de Areilza para una embajada tan relevante como la de Francia, coincidiendo con el inicio de un acercamiento hispano-francés que prometía ser muy provechoso para el régimen español, pone de manifiesto que a pesar de sus inclinaciones monárquicas y demoliberales, evidenciadas durante sus seis exitosos años como embajador en los Estados Unidos, Motrico continuaba disfrutando, a la sazón, del pleno respaldo del Ministerio de Asuntos Exteriores y del jefe del Estado.

Como jefe de misión en Francia, Areilza, habiéndose ganado la confianza tanto del presidente De Gaulle, como del ministro Couve de Murville, trabajó con tenacidad para contribuir al fortalecimiento de las relaciones hispano-francesas, acercamiento que, así lo creían tanto Motrico como Castiella, debía facilitar el acercamiento de España al Mercado Común. La nutrida presencia de activistas de la Algerie Française en territorio español, donde contaban con probadas complicidades, resultó un obstáculo al anhelado mejoramiento de las relaciones entre los dos países. No obstante, tratando tanto con las más altas autoridades de la V República como con los detractores más recalcitrantes del presidente De Gaulle, y exhortando reiteradamente a la prudencia mediante las cartas que remitió al Palacio de Santa Cruz, Areilza contribuyó con sus gestiones a que el régimen franquista no fuera visto por las autoridades francesas como favorable a los militares rebeldes y a la OAS, consolidando de esta manera el acercamiento entre los dos países. Aproximación que, empero, no culminaría en una alianza formal debido al insuficiente interés francés y a las reservas que semejante vínculo, potencialmente incompatible con los acuerdos bilaterales con los Estados Unidos, suscitaba en el Gobierno español. Los sentidos elogios que con motivo de su cese como embajador le dedicaron el presidente de la República, quien quiso despedirle personalmente, el primer ministro y otras altas autoridades francesas, así como los representantes de la comunidad española residente en Francia, demuestran el éxito que Areilza obtuvo en la tarea de contribuir al mejoramiento de las relaciones hispanofrancesas.

No obstante, las misivas y despachos a los que se ha tenido acceso en el fondo del Ministerio de Asuntos Exteriores permiten matizar el testimonio que sobre sus gestiones a propósito del conflicto argelino ofrece Areilza en su testimonio retrospectivo, especialmente en Memorias exteriores. Así, si en sus memorias, género intrínsecamente autojustificativo, Motrico se refiere a su labor como incondicionalmente favorable al Gobierno francés, absolutamente contraria a los enemigos del presidente de Gaulle y gravemente dificultada, además, por los apoyos que éstos tenían en el seno de la dictadura española, la documentación primaria muestra a un Areilza notablemente más pragmático y precavido. Su juicio inicial sobre el general Salan, formado 
tras la entrevista mantenida con él en octubre de 1960, no fue en absoluto negativo y, un mes más tarde, encontrándose ya Salan en territorio español, Areilza hizo ver a Castiella la necesidad de proceder con cautela y de cultivar los contactos forjados en ambos bandos por él mismo. No fue hasta enero de 1961, coincidiendo con el referéndum sobre la autodeterminación de Argelia, cuando Motrico se refirió críticamente a Salan y procedió a descalificar los argumentos esgrimidos por los partidarios de la Algerie Française contra De Gaulle. No obstante, al producirse el golpe militar de abril de 1961, el embajador español, en una postura que solamente cabe describir como sensata, volvería a plantear la adopción de una política de estricta neutralidad, habida cuenta de que la insurrección podía triunfar, en cuyo caso los militares golpistas estarían obligados a estrechar los vínculos con España. Fracasada la insurrección, Areilza procedería, ya sí, a plantear abiertamente al Palacio de Santa Cruz la necesidad de restringir las actividades de los antigaullistas radicados en territorio español, con objeto de obtener de las autoridades francesas tanto el apoyo expreso a la integración de España a las Comunidades Europeas como la represión de los exiliados antifranquistas al norte de los Pirineos.

El contenido de las cartas a Castiella y, muy especialmente, las misivas remitidas al general Franco atestiguan que, como embajador en Francia, al igual que había hecho previamente tanto en Buenos Aires como en Washington, Areilza se condujo siempre como un embajador "político», investido de amplios poderes para tratar asuntos que revestían una considerable complejidad y trascendencia, como la complicidad de ciertos sectores del régimen español con el núcleo dirigente de la OAS o la conveniencia de restringir las actividades de la oposición española en Francia, directamente con el ministro Couve de Murville o con el mismísimo general De Gaulle. Del lenguaje franco y directo empleado en las cartas dirigidas al Palacio de Santa Cruz se desprende que Motrico, quien nunca dejó de ser y de sentirse una personalidad de gran autoridad en la vida política española, seguía considerando a Castiella en este periodo como un colega al que podía permitirse aconsejar y de quien podía, incluso, disentir.

Sea como fuere, el ingreso de la España de Franco en el Mercado Común, una meta que Motrico consideraba indispensable para la plena integración de España en la sociedad internacional y un estímulo a la democratización del régimen, se reveló inviable debido tanto al mencionado inmovilismo de las autoridades españolas como al insuficiente compromiso del Gobierno de la V República con la petición española, pese al estrechamiento experimentado por las relaciones hispano-francesas en aquel periodo. Un entendimiento al que Areilza contribuyó decididamente al ganarse la confianza de las más altas magistraturas francesas durante una coyuntura crítica para la V República y para el porvenir democrático de Francia. 


\section{Bibliografía}

Areilza, José María de, «Lo esencial y lo episódico», Revista de Estudios Políticos, 11-12 (Madrid, 1943): 67-68.

Areilza, José María de, Así los he visto, Barcelona, Editorial Planeta, 1974.

Areilza, José María de, Diario de un ministro de la monarquía, Barcelona, Editorial Planeta, 1977. Colección Espejo de España, 36.

Areilza, José María de, Memorias exteriores 1947-1964, Barcelona, Editorial Planeta, 1984. Colección Espejo de España, 96.

Areilza, José María de, Crónica de libertad, Barcelona, Editorial Planeta, 1985. Colección Espejo de España, 112.

Areilza, José María de y Castiella, Fernando María, Reivindicaciones de España. Madrid, Instituto de Estudios Políticos, 1941.

Bassols, Raimundo, Veinte años de España en Europa, Madrid, Estudios de Política Exterior, Biblioteca Nueva, 2007a.

Bassols, Raimundo, «España y las Comunidades Europeas», en Marcelino Oreja Aguirre y Rafael Sánchez Mantero (coords.), Entre la historia y la memoria. Fernando María Castiella y la política exterior de España, Madrid, Real Academia de Ciencias Morales y Políticas, 2007b: 219-242.

Bidault, Georges, D'une resistance a l'autre, París, Les Presses du Siècle, 1965.

Cañadas, Gabriel, «Castiella y la política de descolonización», en Marcelino Oreja Aguirre y Rafael Sánchez Mantero, (coords.), Entre la historia y la memoria. Fernando María Castiella y la política exterior de España, Madrid, Real Academia de Ciencias Morales y Políticas, 2007: 55-80.

Crespo MacLennan, Julio, España en Europa 1945-2000, Madrid, Marcial Pons Historia, 2004.

De Gaulle, Charles, Memorias de esperanza. La renovación, 1958-1962, traducción de Florentino Trapero, Madrid, Taurus Ediciones, 1970.

Dulphy, Anne, «La guerre d'Algérie dans les relations Franco-espagnoles», Cahiers de la Méditerranée [online], 71 (2005), doi: https://doi.org/10.4000/cdlm.934

Fenby, Jonathan, The General. Charles De Gaulle and the France he saved, Nueva York, Skyhorse Publishing, 2011.

Franco Salgado-Araujo, Francisco, Mis conversaciones privadas con Franco, Barcelona, Editorial Planeta, 1976. Colección Espejo de España, 25.

Horne, Alistair, A savage war of peace. Algeria 1954-1962, Nueva York, New York Review of Books, 2006. [1977].

Moravcsik, Andrew, «De Gaulle and European Integration: Historical Revision and Social Science Theory», en Center for European Studies Working Paper Series, Program for the Study of Germany and Europe, Working Paper Series 8.5, Cambridge, Universidad de Harvard, 1998: 1-84.

Oreja Aguirre, Marcelino, Memoria y esperanza. Relatos de una vida, Madrid, La Esfera de los Libros, 2011.

Pardo, Rosa, «Fernando María Castiella: pasión política y vocación diplomática», Historia Contemporánea, 15 (Bilbao, 1996): 225-239. 
Pardo, Rosa, «La salida del aislamiento: la década de los cincuenta», en Abdón Mateos López (ed.), La España de los cincuenta, Madrid, Ediciones Eneida, 2008: 109-134.

Perinat, Luis Guillermo, Recuerdos de una vida itinerante, Madrid, Compañía Literaria, 1996.

Pino, Domingo del, «España-Argelia durante el franquismo. Las difíciles relaciones de dos países inacabados», en Antonio Marquina Barrio (ed.), Las relaciones hispano-argelinas. Contexto histórico, desafios y proyectos comunes, Madrid, Foro Hispano-argelino, 2012: 19-41.

Ribeiro de Meneses, Filipe, Salazar. Uma biografia política, Alfragide, Portugal, Publicações Dom Quixote, 2009.

Salan, Raoul, Mémoires: fin d'un empire. L’Algerie, de Gaulle et moi, París, Presses de la Cité, 1974.

Sánchez, Esther M., «Franco y de Gaulle. Las relaciones hispano-francesas de 1958 a 1969», Studia Historica. Historia Contemporánea, 22 (Salamanca, 2004): 105136.

Sánchez, Esther M., Rumbo al sur. Francia y la España del Desarrollo, 1958-1969, Madrid, Consejo Superior de Investigaciones Científicas, 2006.

Saña, Heleno, El franquismo sin mitos. Conversaciones con Serrano Suñer, Barcelona, Grijalbo, 1981.

Segura Varelo, Gastón, A la sombra de Franco. El refugio español de los activistas franceses de la O.A.S., Barcelona, Ediciones B, 2004.

Sempere Juan David, Los «pieds-noirs» en Alicante: las migraciones inducidas por la descolonización, Alicante, Publicaciones de la Universidad de Alicante, 1997.

Serrano Suñer, Ramón, Memorias. Entre el silencio y la propaganda, la Historia como fue, Barcelona, Editorial Planeta, 1977.

Suárez, Luis, Francisco Franco y su tiempo, Madrid, Fundación Nacional Francisco Franco, 1984, vol. VI.

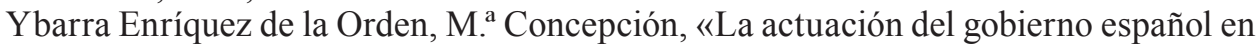
la independencia de Argelia» en Bernabé López García y Miguel Hernando de Larramendi (eds.), España, el Mediterráneo y el mundo árabo-musulmán. Diplomacia e historia, Barcelona, Icaria, 2010: 147-160.

Recibido: 31/07/2019

Aceptado: 1/12/2020 